\title{
SIGNIFICANCE OF N-BIOFIXATION AND FOLIAR SPRAY WITH Zn AND Co ELEMENTS FOR IMPROVING FABA BEAN PRODUCTIVITY UNDER FIELD CONDITIONS OF MIDDLE NILE DELTA AREA, EGYPT
}

\author{
Ali A. Massoud, Mohamed M. EI Kholy, Sayed A. El-Tohamy and \\ Samir F. El Fiki \\ Soils, Water and Environment Res. Inst., Agric. Res. Center, Giza, Egypt.
}

\begin{abstract}
:
A field experiment was conducted on a clayey soil during two successive winter seasons of 2007-2008 and 2008-2009 at Damas village, Mit Ghamer district, El Dakahlia Governorate, Egypt to evaluate the effectiveness of seed inoculation with rhizobium and foliar spray with zinc and cobalt on faba bean (Vicia faba L.) yield and its components as well as seed protein and nutrient contents. Zinc and cobalt sulphates were applied at three rates of 0 , 250 and $500 \mathrm{mg} \mathrm{L}^{-1}$ for $\mathrm{Zn}$ and 0,15 and $25 \mathrm{mg} \mathrm{L}^{-1}$ for Co. Yield and its components (i.e., number of tillers plant ${ }^{-1}$ ), number \& dry weight of nodules and nitrogenase activity of root nodules plant ${ }^{-1}$ at two investigated periods of 45 and 70 days from sowing as well as number of pods plant ${ }^{-1}$, grain contents of protein and elements (i.e., N, P, K, Fe, $\mathrm{Zn}, \mathrm{Cu} \& \mathrm{Co}$ ). Soil content of available nitrogen forms $\left(\mathrm{NH}_{4}{ }^{+}\right.$and $\left.\mathrm{NO}_{3}{ }^{-}\right)$after 70 days from sowing and at harvest were taken into consideration in this study.

The obtained data show that seed inoculation with rhizobium inoculation and foliar spray with $\mathrm{Zn}$ and Co led to a significantly increased in each of tiller plant ${ }^{-1}$, number of pods plant ${ }^{-1}$, grain protein, grain and straw yields in $\mathrm{kg} \mathrm{fed}^{-1}$. A parallel trend was occurred for the positive effect of the applied treatments on faba bean grain contents of N, K, Fe, $\mathrm{Zn}, \mathrm{Cu}$ and $\mathrm{Co}$, however, the greatest values were achieved at the highest rates of 500 and 25 $\mathrm{mg} \mathrm{L} \mathrm{L}^{-1}$ of $\mathrm{Zn}$ and $\mathrm{Co}$, respectively. On the other hand, no changes were observed for grain content of $\mathrm{P}$ by increasing the applied $\mathrm{Zn}$ and Co rates, may be due to the antagonism between $\mathrm{Zn}$ and $\mathrm{P}$.

As for the beneficial effects of the applied treatments on the available nitrogen content in the experimental soil, data show that seed rhizobium inoculation as well as $\mathrm{Zn}$ and $\mathrm{Co}$ as foliar application resulted in a noticeable increase for available content of nitrogen forms $\left(\mathrm{NH}_{4}{ }^{+}\right.$and $\left.\mathrm{NO}_{3}{ }^{-}\right)$at both investigated periods of 70 days after sowing and at harvest as compared to the control treatment. At the same times, it is noticed that the available $\mathrm{N}$-forms gave the greatest values at 70 days after sowing as well as in case of $\mathrm{Zn}$ foliarly as compared to at harvest and case of Co. This was true, since such increase was more closely to the nitrogenase activity. It is noteworthy to mention that seed inoculation and $\mathrm{Zn}$ or Co foliar application showed a parallel trend for the pronounced increases of all tested plant and soil parameters as compared to the control treatment under both studied growing season conditions. So, it could be said that the residual effect of N-biofixation in the soil after harvest leading to rationalize use of $\mathrm{N}$-mineral fertilizers for the next crop, which is surplus point for sustainable agriculture system.
\end{abstract}

Key words: Faba bean, N-biofixation, $\mathrm{Zn}$ or Co foliar spray, available nutrients in the soil and seed nutrient contents.

Fayoum J. Agric. Res. \& Dev., Vol.24, No.1, January, 2010 


\section{INTRODUCTION:}

The symbiotic relation between higher plants and soil microorganisms represents one of the most striking biological phenomena. The use of symbiotic is more economical and much better than the use of chemical fertilizers, which had raised serious objection and real concern about the environmental pollution. The use of a symbiotic bacterium (rhizobium) produces enough nitrogen to support the building up of the whole protein requirements of the legumes (Bedrous et al., 1990).

Faba bean (Vicia faba L.) is one of the principle food legume crop in Egypt as a source of vegetable protein. It serves as an important source of protein in the human diet, especially for those with low income. In addition, faba bean plants improve the fertility of the soil via providing a substantial input of N2 through fixation. Abdel-Maksoud et al. (1985) showed that faba bean was highly responsive to inoculation with selective rhizobia strains and this was reflected on increments of seed yield and nitrogen content.

Cobalt is an important element to the plant growth, however, bacteria on root nodules of legumes (beans, alfalfa and clover) require cobalt and other trace elements to synthesize B12 and fix nitrogen from air (Smith. 1991). Although it is needed by rhizobia in root nodules of leguminous plants, the mechanism by which Co affects plants is not yet clearly known. Soybeans grown without cobalt are severely retorted in growth and exhibit severe nitrogen deficiency, leading to death in about one of four plants. Adding only a few ounces of cobalt per acre can resolve deficiency symptoms in ten to 21 days (Hala Kandil, 2007).

In plants, zinc plays an important role as a structural constituents or regulatory co-factor in a wide range of enzymes in many important biochemical pathways (Moore and Patrick, 1989). There are mainly involved in: carbohydrate metabolism (photosynthesis and conversion of sugars to starch), protein metabolism (deficient plants often have reduced protein contents and elevated concentrations of certain free amino acids), auxin (growth regulator) metabolism (resulting stunning and/or resetting) and pollen formation (reduced production of pollen leads to a proportion of empty grains in the ears of self-pollinating cereals), Moore and Patrick (1989) and Romheld and Marchner (1991).

\section{MATERAL AND METHODS:}

A field experiment was conducted on a clayey soil during two successive seasons of 2007-2008 and 2008-2009 at Damas village, Mit Ghamer district, El Dakahlia Governorate, Egypt. This study aimed to evaluate the effect of rhizobium leguminosarum bv. viciae (nitrogen fixing bacteria) and foliar spray with zinc and cobalt on soil content of available nitrogen forms (i.e., $\mathrm{NH}_{4}{ }^{+}$and $\mathrm{NO}_{3}$ ) at both periods of 70 days after sowing and harvest. Also, faba bean yield and its components (i.e., number of tillers plant ${ }^{-1}$ ) and nodulation characters (i.e., number \& dry weight of nodules and nitrogenase activity of root nodules plant ${ }^{-1}$ ) at two investigated periods of 45 and 70 days from sowing were determined. Number of pods plant ${ }^{-1}$, grain contents of protein and elements (i.e., N, P, K, Fe, $\mathrm{Zn}, \mathrm{Cu} \& \mathrm{Co}$ ).were taken into consideration in this study.

The experiment was designed in split-split design and comprised 18 treatments in three replicates. The main plots are represented by seed

Fayoum J. Agric. Res. \& Dev., Vol.24, No.1, January, 2010 
SIGNIFICANCE OF N-BIOFIXATION AND FOLIAR SPRAY WITH.. 63 inoculated with rhizobium and the sub-plots with $\mathrm{Zn}$ and $\mathrm{Co}$ as foliar spraying. The plot area is $10.5 \mathrm{~m}^{2}$ (3x3.5 m, i.e., 1/400 fed). Faba bean seeds were sown on rows $(50 \mathrm{~cm}$ in width), with hills containing two seeds each with $20 \mathrm{~cm}$ apart at $9^{\text {th }}$ November in both agricultural growing winter seasons.

Some physical and chemical properties of the experimental soil were determined by using the standard methods as described by Black et al. (1965), Hesse (1971) and Jackson (1976), and the obtained data are present in Table (1).

Table (1): Some characteristics of the studied experimental soil at initial state.

\begin{tabular}{|c|c|c|c|}
\hline Soil character & Value & Soil character & Value \\
\hline \multicolumn{2}{|l|}{ Particle size distribution \%: } & $\mathrm{pH}(1: 2.5$,soil suspension $)$ & 7.50 \\
\hline Sand & 15.70 & \multicolumn{2}{|c|}{ Chemical analysis of soil paste extract: } \\
\hline Silt & 39.30 & $\operatorname{ECe}\left(\mathrm{dS} \mathrm{m}^{-1}\right)$ & 2.73 \\
\hline Clay & 45.00 & \multicolumn{2}{|c|}{ Soluble cations $\left(m_{\text {molc }}{ }^{L-} 1\right):$} \\
\hline Textural class & Clay & \multicolumn{2}{|c|}{\begin{tabular}{l|l}
$\mathrm{Ca}^{++}$ & 17.20
\end{tabular}} \\
\hline $\mathrm{CaCO}_{3}$ content $\%$ & 2.80 & \multirow{4}{*}{\multicolumn{2}{|c|}{$\begin{array}{l}\mathrm{Mg}^{++} \\
\mathrm{Na}^{+} \\
\mathrm{K}^{+} \\
\text {Soluble cations }\left(\mathrm{m} \mathrm{molc}^{L-} 1\right):\end{array}$}} \\
\hline Organic matter content $\%$ & 1.02 & & \\
\hline CEC (c molc kg ${ }^{-1}$ soil) & 41.90 & & \\
\hline Available $\mathrm{N} \quad\left(\mathrm{mg} \mathrm{kg}^{-1}\right)$ & 33.50 & & \\
\hline Available $\mathrm{P} \quad\left(\mathrm{mg} \mathrm{kg}^{-1}\right)$ & 9.64 & \multirow{3}{*}{$\begin{array}{l}\mathrm{CO}_{3}^{--} \\
\mathrm{HCO}_{3}^{-} \\
\mathrm{Cl}^{-}\end{array}$} & 0.00 \\
\hline Available $\mathrm{K} \quad\left(\mathrm{mg} \mathrm{kg}^{-1}\right)$ & 379.40 & & 3.43 \\
\hline Available $\mathrm{Zn}\left(\mathrm{mg} \mathrm{L}^{-1}\right)$ & 1.95 & & 11.32 \\
\hline Available Co $\left(\mathrm{mg} \mathrm{L}^{-1}\right)$ & 0.075 & $\mathrm{SO}_{4}^{--}$ & 12.74 \\
\hline
\end{tabular}

\section{Plant samples:}

Three plants were randomly taken from each plot at 45 and 70 days after sowing to determine number and dry weight $(\mathrm{mg})$ of nodules plant ${ }^{-1}$ and nitrogenase activity of nodules (n mole $\mathrm{C}_{2} \mathrm{H}_{4} \mathrm{~g}^{-1}$ dry nodules $\mathrm{h}^{-1}$ ) as described by Hardy et al. (1976). At harvest plants were cut just above the soil surface to determine faba bean yield and its components as well as grain contents of nutrients (i.e., N, P, K, Fe, $\mathrm{Zn}, \mathrm{Cu} \& \mathrm{Co}$ ) (Jackson, 1976) and grain protein content (A.O.A.C., 1980).

\section{Soil samples:}

Soil samples were collected at 70 days after sowing and at harvest to determine the soil available nitrogen forms of $\mathrm{NH}_{4}^{+}$and $\mathrm{NO}_{3}^{-}$by using Technicon Auto Analyzer according to Markus et al. (1982).

Inoculants of bacteria used:

Rhizobium leguminosarum bv.viciae was kindly supplied by Department of Microbiology, Soils, water and Environment Research Institute. Agric. Res. Center, Giza, Egypt

\section{Faba bean seeds inoculation:}

Faba bean seeds were divided into two portions, the first was sown without inoculation and the second one was inoculated before sowing with rhizobial inoculants using Arabic gum as an adhesive agent.

\section{Mineral fertilizers application:}

Nitrogen fertilizer as urea ( $46 \% \mathrm{~N}$ ) was applied at a rate of $20 \mathrm{~kg} \mathrm{~N}$ fed $^{-1}$ into two equal split doses at 35 and 60 days after sowing, $\mathrm{P}$ and $\mathrm{K}$ fertilizers as

Fayoum J. Agric. Res. \& Dev., Vol.24, No.1, January, 2010 
super phosphate $\left(15.5 \% \mathrm{P}_{2} \mathrm{O}_{5}\right)$ and potassium sulphate $\left(48 \% \mathrm{~K}_{2} \mathrm{O}\right)$ were added at the rates of 100 and $50 \mathrm{~kg} \mathrm{fed}^{-1}$, respectively. Zinc sulphate $\left(\mathrm{ZnSO}_{4} .7 \mathrm{H}_{2} \mathrm{O}\right)$ and cobalt sulphate were applied to the plants as foliar application at three rates, i.e., 0,250 and $500 \mathrm{mg} \mathrm{L}^{-1}$ for $\mathrm{Zn}$ and $0,15,25 \mathrm{mg}$ $\mathrm{L}^{-1}$ for Co.

At the end of the experiments, the plants were harvested and the faba bean yield was recorded. The grains were ground and kept in tight bags for chemical analysis. The dried materials of seeds were digested according to Peterburgski (1968). Nitrogen was determined using microkjeldahl, phosphorus by stannous chloride method as described by A.O.A.C (1980) and $\mathrm{K}$ was determined by using Flame Photometer (Yamagnchi and Minges 1956). $\mathrm{Zn}, \mathrm{Fe}, \mathrm{Cu}$ and $\mathrm{Co}$ were determined using Atomic Absorption Spectrophotometer Perkin Elmer, according to Cottenie et al. (1982).

Statistical analysis:

All data obtained of both the two studied seasons were averaged in a mean value for each of the tested plant and soil parameters, and then statistically analyzed by using L.S.D. at 0.05 as described by Snedecor and Cochran (1980).

\section{RESULTS AND DISCUSSION:}

I. Faba bean yield and its components:

Results in Table (2) reveal that seed rhizobium inoculation significantly increased number of tillers plant ${ }^{-1}$, number of pods plant ${ }^{-1}$, grain protein $\%$, grain and straw yields $\left(\mathrm{kg} \mathrm{fed}^{-1}\right)$. These increases in faba bean yield and its components are more attributed to the increase of nitrogen biofixation in faba bean plants due to increasing nitrogenase activity (Table 3 ). These results are in agreement with those stated by Wang and Patill(1995) and Vessey (2004) who showed that rhizobium inoculation enhanced seed yield and its components of pea and other legumes.

Table (2): Effect of seed inoculation and different applied rates of $\mathrm{Zn}$ and Co as foliar application on faba bean yield and its components.

\begin{tabular}{|c|c|c|c|c|c|c|c|}
\hline \multicolumn{3}{|c|}{ Treatment } & \multirow{3}{*}{$\begin{array}{l}\text { No. of } \\
\text { tillers } \\
\text { plant }^{-1}\end{array}$} & \multirow{3}{*}{$\begin{array}{l}\text { No. of } \\
\text { pods } \\
\text { plant }^{-1}\end{array}$} & \multirow{3}{*}{$\begin{array}{c}\text { Grain } \\
\text { yield }(\mathrm{kg} \\
\left.\text { fed }^{-1}\right)\end{array}$} & \multirow{3}{*}{$\begin{array}{c}\text { Grain } \\
\text { protein } \\
\%^{*}\end{array}$} & \multirow{3}{*}{$\begin{array}{c}\text { Straw } \\
\text { yield }(\mathrm{kg} \\
\left.\text { fed }^{-1}\right)\end{array}$} \\
\hline \multirow{2}{*}{$\begin{array}{c}\text { Seed } \\
\text { inoculation }\end{array}$} & \multicolumn{2}{|c|}{$\begin{array}{l}\text { Applied rates of foliar } \\
\text { spray }\left(\mathrm{mg} \mathrm{L}^{-1}\right)\end{array}$} & & & & & \\
\hline & $\mathrm{Zn}$ & $\mathrm{Co}$ & & & & & \\
\hline \multirow{3}{*}{$\begin{array}{c}\text { Un- } \\
\text { inoculation }\end{array}$} & 0 & 0 & 3.35 & 13.80 & 1246.35 & 22.75 & 972.80 \\
\hline & 250 & 25 & 3.65 & 15.35 & 1383.85 & 25.70 & 1082.90 \\
\hline & 500 & 50 & 3.75 & 16.35 & 1537.15 & 27.30 & 1180.65 \\
\hline \multicolumn{3}{|c|}{ Mean } & 3.60 & 15.15 & 1388.95 & 25.25 & 1078.80 \\
\hline \multirow{3}{*}{ Inoculation } & 0 & 0 & 4.40 & 17.75 & 1527.65 & 24.60 & 1184.80 \\
\hline & 250 & 25 & 5.20 & 19.95 & 1737.60 & 28.10 & 1343.90 \\
\hline & 500 & 50 & 7.85 & 22.50 & 1972.70 & 31.45 & 1504.15 \\
\hline \multicolumn{3}{|c|}{ Mean } & 5.82 & 20.10 & 1745.98 & 28.05 & 1344.28 \\
\hline \multicolumn{8}{|c|}{ L.S.D. at 0.05} \\
\hline \multicolumn{3}{|c|}{ Seed inoculation } & 0.44 & 1.74 & 155 & 1.80 & 122 \\
\hline \multicolumn{3}{|c|}{$\mathrm{Zn}$ and Co rates } & 0.54 & 2.13 & 190 & 2.33 & 149 \\
\hline
\end{tabular}

Grain N-content \% x 6.25 (Deyoe and Shellenberger, 1965)

Fayoum J. Agric. Res. \& Dev., Vol.24, No.1, January, 2010 
SIGNIFICANCE OF N-BIOFIXATION AND FOLIAR SPRAY WITH.. 65

Data also showed that foliar application of $\mathrm{Zn}$ and Co led to significantly increases in faba bean yield and its components at both the first and second seasons. The greatest values of these parameters were obtained at the highest rates of both $\mathrm{Zn}$ and $\mathrm{Co}$ (i.e., $500,25 \mathrm{mg} \mathrm{L}^{-1}$, respectively), with a more effectiveness for $\mathrm{Zn}$ than Co. The noticeable increases in faba bean yield and its components as a result of $\mathrm{Zn}$-foliar application could be attributed to the increase in the number of tillers and pods per plant. Similar results were reported by El-Mansi et al. (1990) on pea. As for Co-foliar spraying, Ibrahim et al. (1989) and El-Gizawy and Mehasen (2009) showed that the positive effect of Co-foliar spray on faba bean plants, as compared to the control, may be due to its effective role on many developmental processes such as stem and coleoptiles' elongation, leaf disc expansion and bud development. Also, the proper doses of cobalt may help in better nodulation, and consequently a better growth and yield (Jana et al., 1994).

II. Nodule numbers, their dry weights and nitrogenase activity:

Biological $\mathrm{N}_{2}$-fixation by legume rhizobia symbioses is vitally important as $\mathrm{N}$ input in agro-ecosystem. Table (3) show that seed inoculation with rhizobium significantly increased number of nodules, their dry weights and nitrogenase activity after 45 and 70 days of sowing. These results are in line with those reported by Abdel-Ghaffar et al. (1994) and Massoud et al. (2008) on pea plants and other legumes. While, the presence of active nitrogenase enzyme in nodules for un-inoculated plants is owing to the indigenous rizobia in soil (Mowad and Abd-El Rahim, 2002).

Table (3): Effect of seed inoculation and different applied rates of $\mathrm{Zn}$ and Co as foliar application on nodulation of faba bean roots.

\begin{tabular}{|c|c|c|c|c|c|c|c|c|}
\hline \multicolumn{3}{|c|}{ Treatment } & \multicolumn{2}{|c|}{$\begin{array}{c}\text { Nodule Nos. } \\
\text { plant }^{-1}\end{array}$} & \multicolumn{2}{|c|}{$\begin{array}{l}\text { Nodule dry } \\
\text { weights } \\
\text { (mg) plant }\end{array}$} & \multicolumn{2}{|c|}{$\begin{array}{c}\text { N2-activity } \\
\left(\mathrm{C}_{2} \mathrm{H}_{4} \mathrm{~g}^{-1} \text { plant }^{-1}\right)\end{array}$} \\
\hline \multirow{2}{*}{$\begin{array}{c}\text { Seed } \\
\text { inoculation }\end{array}$} & \multicolumn{2}{|c|}{$\begin{array}{c}\text { Applied rates of } \\
\text { foliar spray }\left(\mathrm{mg} \mathrm{L}^{-1}\right)\end{array}$} & \multicolumn{6}{|c|}{ Days from sowing } \\
\hline & $\mathrm{Zn}$ & $\mathrm{Co}$ & 45 & 70 & 45 & 70 & 45 & 70 \\
\hline \multirow{3}{*}{$\begin{array}{c}\text { Un- } \\
\text { inoculation }\end{array}$} & 0 & 0 & 15.05 & 10.25 & 31.65 & 21.85 & 151.65 & 109.20 \\
\hline & 250 & 25 & 17.15 & 12.45 & 36.15 & 25.45 & 170.40 & 125.65 \\
\hline & 500 & 50 & 18.50 & 13.50 & 38.40 & 26.95 & 179.85 & 133.00 \\
\hline \multicolumn{3}{|c|}{ Mean } & 16.90 & 12.05 & 35.40 & 24.70 & 167.30 & 122.60 \\
\hline \multirow{3}{*}{ Inoculation } & 0 & 0 & 29.20 & 22.60 & 76.70 & 53.70 & 315.65 & 220.30 \\
\hline & 250 & 25 & 35.60 & 26.85 & 91.15 & 62.95 & 364.15 & 259.40 \\
\hline & 500 & 50 & 39.65 & 30.40 & 105.20 & 72.65 & 396.00 & 292.70 \\
\hline \multicolumn{3}{|c|}{ Mean } & 34.82 & 26.62 & 91.02 & 63.10 & 358.60 & 257.47 \\
\hline \multicolumn{9}{|c|}{ L.S.D. at 0.05} \\
\hline \multicolumn{3}{|c|}{ Seed inoculation } & 2.60 & 3.40 & 10.90 & 7.36 & 25.22 & 27.33 \\
\hline \multicolumn{3}{|c|}{$\mathrm{Zn}$ and Co rates } & 3.20 & 4.11 & 13.40 & 9.00 & 30.88 & 33.47 \\
\hline
\end{tabular}

Data in Table (3) show that number and dry weights of nodules and their dry weights after 45 and 70 days of sowing exhibited significantly increases as a result of foliar spray with the applied rates of $\mathrm{Zn}$ and Co. Such mentioned investigated scope tended to gradual increases with increment of $\mathrm{Zn}$ and $\mathrm{Co}$

Fayoum J. Agric. Res. \& Dev., Vol.24, No.1, January, 2010 
rates up to the highest ones of 500 and $25 \mathrm{mg} \mathrm{L}^{-1}$, respectively. These results are in agreement with those obtained by Vessey (2004).

The positive effect of zinc on nodulation and nitrogenase activity may be due to its role which acts as metal component for some enzyme or as a functional or regulatory co-factor for the others, hence zinc increase root nodulation and nitrogenase activity by indirect way. The same results were obtained by Abadi et al. (1995) who attributed the effect of zinc on nodulation and nitrogenase activity to the improved nutritional status of rhizobium. While, the positive effect of Co on nodulation and nitrogenase activity may be attributed to the role of $\mathrm{Co}$ as an essential component of nitrate reductase and nitrogenase enzyme, which controls the reduction of nitrogen (Fixing $\mathrm{N}_{2}$ to $\mathrm{NH}_{3}$ ) and promotes the nodules formation of legumes. Similar results are reported by Jana et al. (1994) and Abd El-Moez and Nadia Gad (2002) who found that cobalt addition increased the nodules formation of root and atmospheric nitrogen fixation by microorganisms, which increased the nitrogen content in faba bean plants.

It is worthy to mention that a parallel trend for increased both number of nodules and their dry weights took place with the nitrogenase activity after either 45 or 70 days from sowing, which are more affected by seed rhizobia inoculation and applied foliar spray with both $\mathrm{Zn}$ and Co elements. These results showed a close relationship between the nodulation phenomenon and the activity of symbiotic bacteria, especially in the rhizosphere zone

III. Macro and micronutrients status in faba bean grains:

Grain element contents of $\mathrm{N}, \mathrm{P}, \mathrm{K}, \mathrm{Fe}, \mathrm{Zn}, \mathrm{Cu}$ and $\mathrm{Co}$ are presented in Table (4), and showed that faba bean seed rhizobium resulted in a significantly increase for each of all tested elements, except $\mathrm{P}$, as compared to the uninoculated one either in the first or second seasons.

Table (4): Effect of seed inoculation and different applied rates of $\mathrm{Zn}$ and Co as foliar application on element contents of faba bean grains.

\begin{tabular}{|c|c|c|c|c|c|c|c|c|c|}
\hline \multicolumn{3}{|c|}{ Treatment } & \multicolumn{3}{|c|}{ Macronutrients \% } & \multicolumn{4}{|c|}{ Microelements ( $\mathrm{mg} \mathrm{kg}^{-1}$ soil) } \\
\hline \multirow{2}{*}{$\begin{array}{c}\text { Seed } \\
\text { inoculation }\end{array}$} & \multicolumn{2}{|c|}{$\begin{array}{c}\text { Applied rates of } \\
\text { foliar spray }\left(\mathrm{mg} \mathrm{L}^{-1}\right)\end{array}$} & \multirow[t]{2}{*}{$\mathbf{N}$} & \multirow[t]{2}{*}{$\mathbf{P}$} & \multirow[t]{2}{*}{$\mathbf{K}$} & \multirow[t]{2}{*}{$\mathbf{F e}$} & \multirow[t]{2}{*}{$\mathbf{Z n}$} & \multirow[t]{2}{*}{$\mathbf{C u}$} & \multirow[t]{2}{*}{ Co } \\
\hline & $\mathrm{Zn}$ & $\mathrm{Co}$ & & & & & & & \\
\hline \multirow{3}{*}{$\begin{array}{c}\text { Un- } \\
\text { inoculation }\end{array}$} & 0 & 0 & 3.35 & 0.22 & 1.35 & 105.00 & 26.00 & 2.85 & 2.85 \\
\hline & 250 & 25 & 3.80 & 0.19 & 1.45 & 109.35 & 28.90 & 4.60 & 4.60 \\
\hline & 500 & 50 & 4.05 & 0.17 & 1.55 & 112.70 & 32.00 & 7.10 & 7.10 \\
\hline \multicolumn{3}{|c|}{ Mean } & 3.75 & 0.19 & 1.45 & 109.00 & 29.00 & 4.15 & 4.15 \\
\hline \multirow{3}{*}{ Inoculation } & 0 & 0 & 3.95 & 0.25 & 1.60 & 122.60 & 30.60 & 3.35 & 3.30 \\
\hline & 250 & 25 & 4.50 & 0.20 & 1.75 & 133.20 & 35.95 & 5.35 & 5.40 \\
\hline & 500 & 50 & 4.75 & 0.19 & 1.95 & 144.15 & 39.90 & 8.55 & 6.55 \\
\hline \multicolumn{3}{|c|}{ Mean } & 4.35 & 0.21 & 1.76 & 133.32 & 35.48 & 5.75 & 5.75 \\
\hline \multicolumn{10}{|c|}{ L.S.D. at 0.05} \\
\hline \multicolumn{3}{|c|}{ Seed inoculation } & 0.16 & 0.07 & 0.10 & 8.48 & 3.82 & 0.63 & 0.61 \\
\hline \multicolumn{3}{|c|}{$\mathrm{Zn}$ and Co rates } & 0.19 & 0.02 & 0.12 & 10.40 & 4.68 & 0.77 & 0.74 \\
\hline
\end{tabular}

These positive effects are more attributed to the increase in bio-fixed nitrogen that increased by nitrogenase activity of rhizobium in root nodules, and consequently increased $\mathrm{N}$ uptake by plants. Such favourable condition

Fayoum J. Agric. Res. \& Dev., Vol.24, No.1, January, 2010 
SIGNIFICANCE OF N-BIOFIXATION AND FOLIAR SPRAY WITH.. 67

encourages the vegetative growth of faba bean plants, hence uptake of the other elements increased from the soil, besides $\mathrm{Zn}$ and co whose are added as foliar application, and accumulated in the different plant organs, particularly faba bean grains. These results are in line with those stated by Daterao et al. (1994) and Massoud et al. (2005) who reported that rhizobium inoculation increased grain nitrogen in pea and other legumes. Similar results were obtained by Massoud (2001) who found that rhizobium inoculation increased nutrient contents in grains of pea. With respect to faba bean grain content $\mathrm{P}$, which showed no noticeable changes as a result of the applied treatments, it may be explained by the antagonism between the applied $\mathrm{Zn}$ as foliar application and the uptake of $\mathrm{P}$ from the soil.

Regarding the effect of foliar application of $\mathrm{Zn}$ and Co on N, P, K, Fe, $\mathrm{Zn}, \mathrm{Cu}$ and $\mathrm{Co}$ in faba bean grains, it is observed gradual increases in the uptake of these elements with increasing the applied rates of $\mathrm{Zn}$ and $\mathrm{Co}$ as foliar application, which reached the greatest contents at the highest rates of 500 and $25 \mathrm{mg} \mathrm{L}^{-1}$, respectively. On the other hand, faba bean grain content of $\mathrm{P}$ exhibited no changes by increasing of $\mathrm{Zn}$ and Co rates, may be due to the antagonism phenomenon as mentioned before. These results are in harmony with those obtained by Massoud et al. (2005) who found that $\mathrm{Zn}$ application as a seed coating or foliar had a positive effect on $\mathrm{N}, \mathrm{K}$, and Mo contents of pea. Also, Dahdoh and Mossa (2000) observed that addition of $\mathrm{Zn}$ or $\mathrm{Co}$ increased plant $\mathrm{N}$ and $\mathrm{K}$ contents vs decreased $\mathrm{P}$ and $\mathrm{Cu}$ in broad bean and peanut plants. Moreover, Hala Kandil (2007) found that Co addition increased faba bean grain contents of macro and micronutrients as well as protein percentage. In this concern, Zhoa et al. (1998) found that, up to the $\mathrm{Zn}$ rate of $20 \mathrm{~g} \mathrm{~kg}^{-1}$, phosphorous content of plant tissues remained at a constant level, and then tends to decrease abruptly when $\mathrm{Zn}$ concentration went above $20 \mathrm{~g} \mathrm{~kg}^{-1}$. This is mainly attributed to $\mathrm{Zn}$ rates stimulate phosphorous content in faba bean grains, due to the antagonism phenomenon between two elements,

IV. Available nitrogen content in the soil as affected by nitrogenase activity:

Data in Table (5) showed the effect seed rhizobium inoculation and foliar application of $\mathrm{Zn}$ and $\mathrm{Co}$ on available content of nitrogen forms (nitrate and ammonium) in the soil after either 70 days from sowing of faba bean or harvesting. Results revealed that the rhizobium inoculation increased Both $\mathrm{NH}_{4}{ }^{+}-\mathrm{N}$ and $\mathrm{NO}_{3}^{+}-\mathrm{N}$ contents in the experimental soil as compared with untreaded one. Similar results were obtained by Massoud et al. (2005). Data also showed that increasing $\mathrm{Zn}$ and $\mathrm{Co}$ as a foliar application increased the contents of available nitrogen forms in the soil, with gradual increments reached the greatest values at the applied highest rates of 500 and $25 \mathrm{mg} \mathrm{L}^{-1}$, respectively. However, $\mathrm{Zn}$ foliar application was more effective for increasing soil content of $\mathrm{NH}_{4}^{+}$and $\mathrm{NO}_{3}^{-}$than that of $\mathrm{Co}$. It is noteworthy to mention that soil available $\mathrm{N}$-forms, i.e., $\mathrm{NH}_{4}{ }^{+}$and $\mathrm{NO}_{3}{ }^{-}$recorded relative increase percentages reached about 92 and $84 \%$ at 70 days after sowing and at harvest, respectively, as compared to the control treatment. This was true, since such increases were more closely attributed to the nitrogenase activity.

Fayoum J. Agric. Res. \& Dev., Vol.24, No.1, January, 2010 
Table (5): Effect of seed inoculation and different applied rates of $\mathrm{Zn}$ and Co as foliar application on soil contents of available nitrogen forms at both 70 days after sowing and harvest.

\begin{tabular}{|c|c|c|c|c|c|c|}
\hline \multicolumn{3}{|c|}{ Treatment } & \multicolumn{4}{|c|}{ Soil content of available forms } \\
\hline \multirow{3}{*}{$\begin{array}{c}\text { Seed } \\
\text { inoculation }\end{array}$} & \multirow{2}{*}{\multicolumn{2}{|c|}{$\begin{array}{c}\text { Applied rates of } \\
\text { foliar spray }\left(\mathrm{mg} \mathrm{L}^{-1}\right)\end{array}$}} & \multicolumn{2}{|c|}{70 days from sowing } & \multicolumn{2}{|c|}{ At harvest } \\
\hline & & & \multirow{2}{*}{$\mathrm{NH}_{4}{ }^{+}$} & \multirow{2}{*}{$\mathrm{NO}_{3}^{-}$} & \multirow{2}{*}{$\mathrm{NH}_{4}{ }^{+}$} & \multirow{2}{*}{$\mathrm{NO}_{3}^{-}$} \\
\hline & $\mathrm{Zn}$ & Co & & & & \\
\hline \multirow{3}{*}{$\begin{array}{l}\text { Un- } \\
\text { inoculation }\end{array}$} & 0 & 0 & 12.25 & 42.65 & 9.40 & 30.50 \\
\hline & 250 & 25 & 17.20 & 45.90 & 13.25 & 34.60 \\
\hline & 500 & 50 & 19.75 & 48.75 & 15.20 & 37.10 \\
\hline \multicolumn{3}{|c|}{ Mean } & 16.41 & 44.77 & 12.65 & 34.07 \\
\hline \multirow{3}{*}{ Inoculation } & 0 & 0 & 21.20 & 73.40 & 15.30 & 49.50 \\
\hline & 250 & 25 & 24.45 & 81.75 & 17.60 & 54.30 \\
\hline & 500 & 50 & 27.60 & 90.60 & 19.90 & 63.90 \\
\hline \multicolumn{3}{|c|}{ Mean } & 24.08 & 81.92 & 17.60 & 55.90 \\
\hline \multicolumn{7}{|c|}{ L.S.D. at 0.05} \\
\hline \multicolumn{3}{|c|}{ Seed inoculation } & 1.68 & 3.80 & 1.30 & 2.9 \\
\hline \multicolumn{3}{|c|}{$\mathrm{Zn}$ and Co rates } & 2.07 & 4.80 & 1.60 & 3.7 \\
\hline
\end{tabular}

The increase of nitrogen forms in soil as a result of foliar application by $\mathrm{Zn}$ or Co may be due to high activation of rhizosphere zone as a constituent of nitrogenase enzyme, hence it increased the bio-fixed $\mathrm{N}_{2}$ in the soil. Similar results were obtained by Vieira et al. (1998) and Massod et al. (2005) who found that seed coated with Mo or $\mathrm{Zn}$ increased the available nitrate and ammonium in the soil after pea harvesting.

\section{CONCLUSION:}

The present study showed that, the combined effect of seed rhizobium inoculation with $\mathrm{Zn}$ and $\mathrm{Co}$ as foliar spray significantly increased faba bean yield and its components. As for the achieved increases in soil available nitrogen forms after either 70 days from sowing or at harvest, it could be said that the residual effect of seed inoculation leading to rationalize use of mineral nitrogen fertilizers for the next crop, which is surplus point for sustainable agriculture system. These data need more investigations on many species of other crops and different rates of these elements, especially Co to justify its effect on plant growth, yield and elemental composition of seeds whether it adds foliarly or soil application under field conditions.

\section{REFERENCES:}

A.O.A.C. (1980). Official Methods of Analysis. Association of Agriculture.

Abadi, Dawlat N.; M.H. Hegazy and Faiza K. Abd El-Fattah (1995). The interaction effect of inoculation and zinc application on growth and yield of soybean. Annals Agric. Sci., Ain Shams Univ., Cairo, 40 (1): 107-116.

Abd El-Moez, M.R. and Sh. Nadia Gad (2002). Effect of organic cotton compost and cobalt application on cowpea plants growth and mineral composition. Egypt. J. Appl. Sci., 17: 426-440.

Fayoum J. Agric. Res. \& Dev., Vol.24, No.1, January, 2010 
Abdel-Ghaffar, A.S.; A.M. Hanna and F.I. Mohamed (1994). Factors affecting nitrogen fixation and yield of faba bean (Vicia faba) under Egyptian field conditions: A review.Arid Land Research and Management, 1 (2): 65-75.

Addel-Maksoud, H.K.; A.S. El Neklawy and M.M. Maatouk (1985). Effect of rhizobium inoculation combined with nitrogen on grain yield of faba bean (Vicia faba) in Noba region, Egypt. Annals, Agric. Sci., Moshtohor, 23: 921-933.

Bedrous, V.S.; A.N. El-Wafi Besada; Y.B. and F.S. Faris (1990). Studies on the interactions between VA. Maycorrhiza, stavins of rhizobium Leguminosarum biovar. Phaseoli and bean cultivates under field condition in Egypt. Zagazig J. Agric. Res., 17 (1): 1-17.

Black, C.A.; D.D. Evans; L.E. Ensminger; J.L. White and F.E. Clark (1965). Methods of Soil Analysis. Am. Soc. of Agron. Inc., Madison, Wisconsin, USA.

Cottenie, A.; M. Verloo; L. Klekens; G. Velghe and Canielnc (1982). Chemical Analysis of Plant and Soil Laboratory. Analytical and Agrochemistry Stata Univ., Ghent-Belgium. $41 \mathrm{pp}$.

Dahdoh, M.S.A. and B.I.M. Moussa (2000). Zn-Co and Fe-Ni interaction and their effect on peanut and broad bean plants. Egypt. J. Soil Sci., 40 (4): 453-467.

Daterao, S.H. Bada; B.V. Deshpande and T.R. Sattiwale (1994). Influence of rhizobium and rhizobium plus molybdenum on nitrogen use efficiency and economy in legumes. J. Soil and Crops, 4 (2): 145-147.

Deyoe, C.W. and J.A. Shellenberger (1965). Amino acids and proteins in sorghum grain. J. Agric. and food Chem., 13:446.

El-Gizawy N.Kh.B and S.A.S. Mehasen (2009). Response of faba bean to bio, mineral phosphorus fertilizers and foliar application with zinc. World Applied Sci. J. 6 (10): 1359-1365.

El-Mansi, A.A.; M.A. El-Beheidi, M.H. EL-Sawah and S.A. Swidan (1990). The importance of interaction of NAA, boron and zinc on peas. I: Plant growth and pigments content. Zagazig J. Res., 17 (2): 361-368.

Hala, Kandil (2007). Effect of cobalt fertilizer on growth, yield and nutrients status of faba bean (Vicia faba L.) plants. J. Appl. Sci. Res., 3 (9): $867-$ 872

Hardy, R.W.F.; R.C. Burns and R.D. Holston (1976). Application of the acetylene-ethylene assay measurement of nitrogen fixation. Soil Biol.Biochem., 5: 47-55.

Hesse, P.R. (1971). A Text Book of Soil Chemical Analysis. John Murroy (Puplish). London, UK.

Ibrahim, A., S.O. El-Abd and A.S. El-Beltagy (1989). A possible role of cobalt in salt tolerance of plant. Egypt J. Soil Sci., 24: 359-370.

Jackson, M.L. (1976). Soil Chemical Analysis. Constable. Co. Lt., London, UK.

Jana, P.K.; S. Karmakar; S. Ghatak; A. Barik; A. Naybri; G. Souda; A.K. Mukher and B.K. Saren (1994). Effect of cobalt and rhizobium on yield, oil content and nutrient concentration in irrigated summer groundnut. Ind. J. Agric. Sci., 64: 630-632.

Fayoum J. Agric. Res. \& Dev., Vol.24, No.1, January, 2010 
Kadar I., F. Gulyas; L. Gaspar and P. Zilahy (2000). Mineral nutrition of maize (Zea mays L.) on chernozem soil I. Novenytermeles, 49 (4): 371-388.

Markus, D.K; J.P. Mekinnon and A.F. Buccafuri (1982). Automated Analysis of Nitrate and Ammonium Nitrogen in Soils. New Jersey, Agric. Exp. Sta. Publication No.D.151117-84, Soil Soc.of Anaheim, CA, USA.

Massoud, A.M. (2001). Effect of molybdenum on nitrogen availability in soil and its metabolism in plant. Ph.D. Thesis, Fac. of agric., Minufiya Univ., Egypt.

Massoud, A.M.; M.Y. Abou-Zeid; A.H. EL-Sayada and S.F. El Fiki (2008). Influence of phosphate dissolving and nitrogen fixing bacteria on faba bean under different levels of phosphorous fertilization. J. Agric. Sci. Mansora Univ., 33 (11): 7991-8007.

Massoud, A.M.; M.Y. Abou-Zeid and M.A. Bakry (2005). Response of pea plants growth on silty clay soil to micronutrients and rhizobium inoculation. Egypt. J. of Appl. Sci., 20 (6A): 329-346.

Moawad, H. and Wafaa M. Abd El-Rahim (2002). Assessment of symbiotic performance of several bean cultivars inoculated with their specific rhizobia. Egypt. J. Microbiol., 37 (3): 247-262.

Moore, P.A. and W.H. Patrick (1989). Effect of zinc deficiency on alcohol hydrogenase activity and nutrients uptake in rice. Agron. J., 80:882885.

Peterburgski, A.V. (1968). Hand Book of Agronomic Chemistry. Kolos Publishing House, Moscow (In Russian pp. 29-86) (c.f.. Shamas ElDin, H.A., 1993, Ph.D. Thesis, Mansoura Univ.).

Romheld, V. and H. Marshschner (1991). Function of micronutrients in plants. In: "Micronutrients In Agriculture." Published by Soil Sci. Soc. Amer.., Inc. Madison, Wisconsin, USA. 297-299 pp..

Smith, R.M. (1991). Trace elements in human and animal nutrition. Micronutrient News and Information, 11: 9 (Abstract).

Snedecor, G.W.and W.G. Cochran (1980). Statistical Methods. $7^{\text {th }}$ Ed. Iowa State Univ. Press, Amer., Iowa, USA.

Vessey, J. K. (2004). Benefits of inoculating legume crops with rhizobia in the northern Great Plains. Online. Crop Management,doi:10.1094/CM2004-0301-04-RV.

Vieira R.F.; E.J.B.N. Cardoso; C. Viera and S.T.A. Cassini (1998). Foliar application of molybdenum in common beans (a). nitrogenase and nitrate reductase activities in a soil of high fertility. J. of Plant Nutrition,. 21 (1): 169-180.

Wange, S.S. and P.L. Patil (1995). Response of pea cultivars to rhizobium inoculation. J. of Mahar. Agric. Univ., (20): 133-134.

Yamaguchi, M. and A.P. Minges (1956). Brown checking of celery, assumption of boron deficiency. I: field observations. Variety Ssusceptibility and Chemical Analysis, Proc.

Zhao FJ.; Z.G. Shen and S.P. McGrath (1998). Solubility of zinc and interactions between zinc and phosphorus in the hyperaccumulator thlaspi caerulescens. Plant Cell and Environment, 21 (1): 108-114.

Fayoum J. Agric. Res. \& Dev., Vol.24, No.1, January, 2010 
SIGNIFICANCE OF N-BIOFIXATION AND FOLIAR SPRAY WITH.. 71 أهمية التثبيت الحيوى للنتروجين والرش بعنصرى الزنك و و الكوبلت فى تحسين إنتاجية الفول

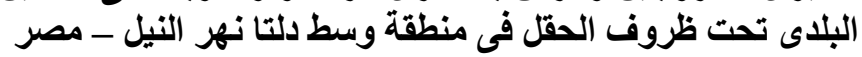

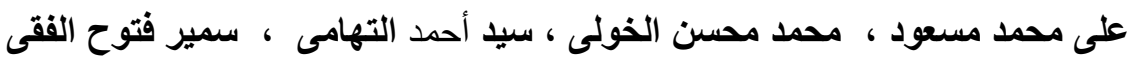

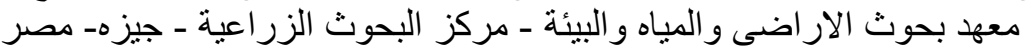

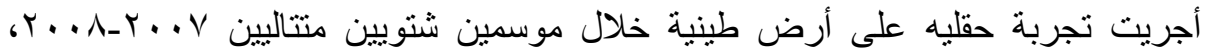

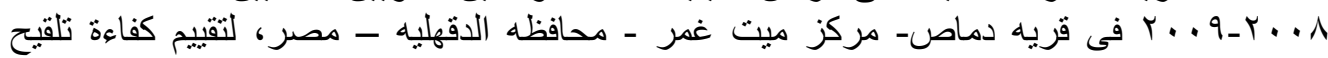

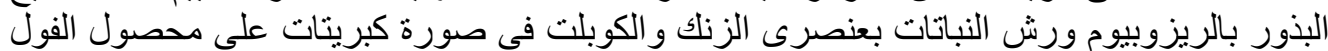

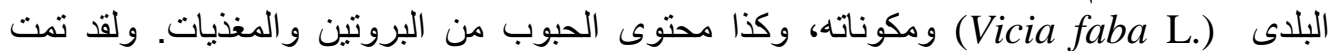

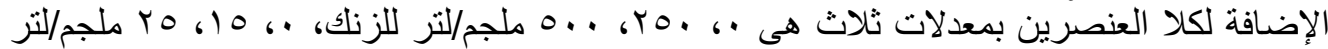

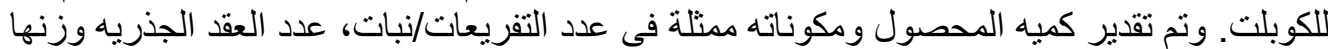

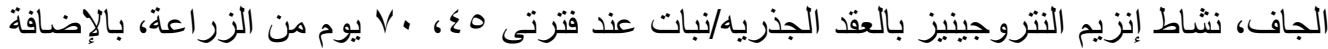

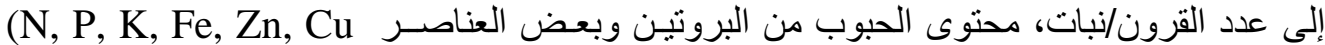

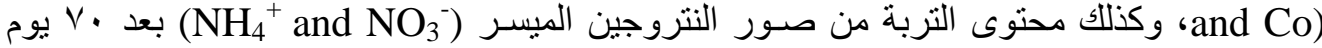
من الزر اعة و عند الحصاد.

وتشير النتائج المتحصل عليها إلى أن تلقيح البذور بالريزوبيوم ورش النباتات بالزنك

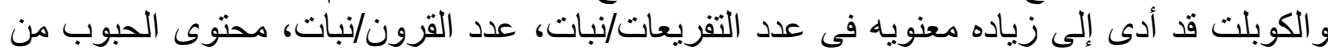

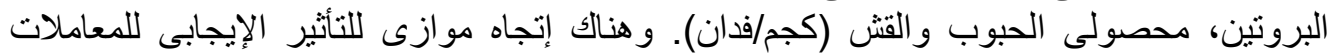

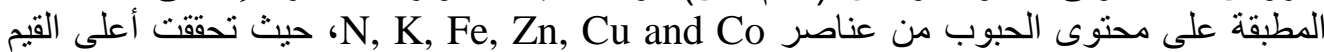

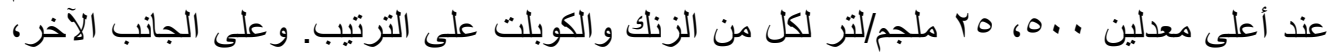

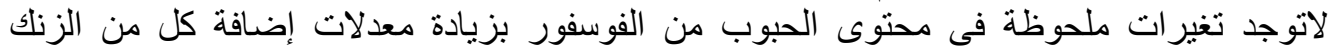

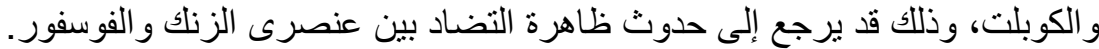

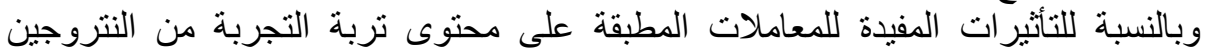

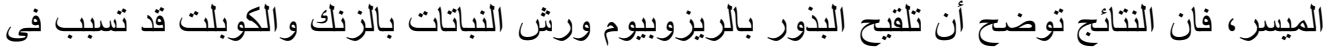

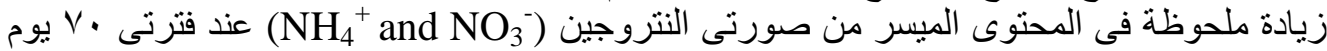

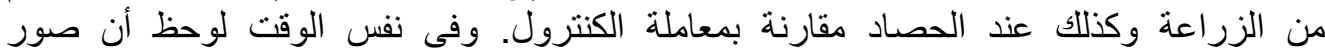

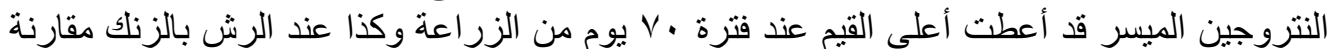

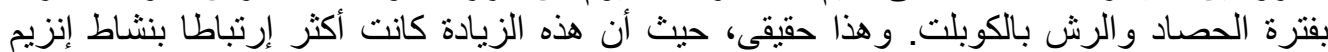

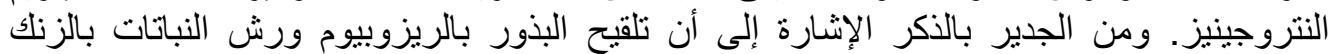

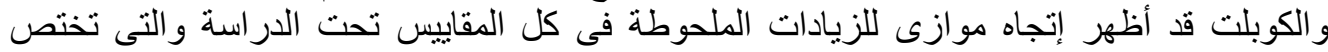

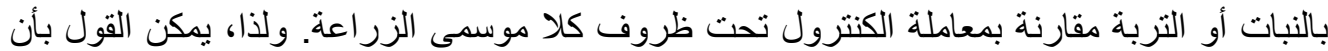

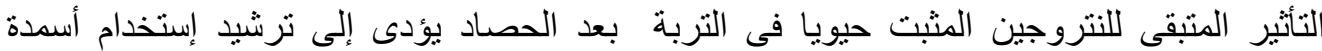

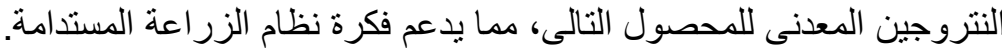

Fayoum J. Agric. Res. \& Dev., Vol.24, No.1, January, 2010 